\title{
Evidence for existence of two types of massive obesity
}

\author{
P G KOPELMAN， T R E PILKINGTON， N WHITE，S L JEFFCOATE
}

\section{Summary and conclusions}

The responses of growth hormone, cortisol, and prolactin to symptomatic hypoglycaemia during an intravenous insulin tolerance test were measured in 20 massively obese subjects and six lean volunteers. In 11 subjects, who had been obese since early childhood, an impaired growth-hormone response and an absent prolactin response were found. In the nine other obese subjects, however, the growth-hormone and prolactin responses were not significantly impaired. Seven of these subjects had become obese either as a teenager or during adult life.

These findings suggest the existence of two types of human obesity similar to those found in rodent models. In one the disorder of hypothalamic function may be due to a basic, possibly genetic abnormality, while in the other it is acquired.

\section{Introduction}

We previously reported ${ }^{1}$ an absent prolactin and impaired growth-hormone and cortisol response to insulin-induced hypoglycaemia in a group of massively obese women. We concluded that this was evidence for a change in hypothalamic function in these women, all of whom had been obese since early childhood. We questioned whether a similar abnormal hypothalamopituitary response would occur in massively obese subjects who had become obese in adult life, because in rodent models different patterns of prolactin and growthhormone secretion are seen depending on the aetiology of the obesity. We now report the results of our extended study of 20 massively obese subjects, of whom 13 had been obese since early childhood and seven had become obese as either teenagers or adults.

\section{Patients, methods, and results}

Details of the subjects and controls studied are shown in table I. The obese subjects, whose thyroid function was normal, were studied in hospital while receiving a weight-maintaining diet, and informed consent was obtained for the investigation. Two of these subjects, who were not known to be diabetic, gave abnormal results to oral glucose tolerance tests. No subject was taking any medication. An intravenous insulin tolerance test $(0 \cdot 15$ units soluble insulin $/ \mathrm{kg})$ was performed in the morning after an overnight fast; subjects were rested for at least 30 minutes after the insertion of an intravenous cannula, through which the blood samples were drawn. Blood was taken before and then at 30-minute intervals for two hours after the injection of insulin. Blood glucose concentrations fell to less than $40 \%$ of the fasting value after insulin, and this fall was accompanied by symptoms in all subjects. Each sample was immediately centrifuged and the plasma frozen and stored at $-20^{\circ} \mathrm{C}$ until assay.

Prolactin, growth hormone, and cortisol concentrations were measured by specific radioimmunoassays. The standard used in the prolactin assay was IRP 75/504, and in the growth-hormone assay IRP 66/217. Reagents for the prolactin and cortisol assays were

St George's Hospital and Medical School, London SW17 ORE

P G KOPELMAN, MB, MRCP, research registrar

T R E PILKINGTON, MD, FRCP, professor of medicine

Chelsea Hospital for Women, London W6 OXG

N WHITE, MPHIL, clinical biochemist

$S$ L JEFFCOATE, MRCPATH, professor of biochemical endocrinology provided by the matched reagents programme of the human reproduction unit of the World Health Organisation. Tables I and II show the results of the study and the significance of differences between the groups, the subjects being grouped according to their prolactin response to hypoglycaemia.

\section{Discussion}

We previously reported ${ }^{1}$ impaired growth-hormone and cortisol responses and an absent prolactin response to insulininduced hypoglycaemia in nine massively obese women. Further studies yielded a woman and a man who showed no prolactin response to symptomatic hypoglycaemia. In all of these 11 subjects the obesity had developed at an early age. Our investigations of late-onset obesity have now provided evidence for a separate type of obesity. In subjects who became obese as teengaers or adults the growth-hormone response to hypoglycaemia was not significantly impaired and the prolactin and cortisol responses were normal. A similar pattern of response was also seen, however, in two obese subjects who had been obese as children. No physical features differentiated the two groups.

The existence of two types of human obesity was suggested by Ball et $a l,{ }^{2}$ who found that some obese people regain their growth-hormone response to insulin-induced hypoglycaemia after losing weight whereas others continue to have an impaired response despite remaining at a lower weight for six months. Jung $e t{ }^{3}$ recently described a basic abnormality of thermogenesis in obese women with a strong family history of obesity. This abnormality remains even when these women have lost weight. Interestingly, a similar defect of thermogenesis occurs in the genetically obese ob/ob mouse.

In obese mice with hypothalamic disorders the pattern of prolactin and growth-hormone response depends on the type of obesity. In the ob/ob mouse plasma prolactin and growthhormone concentrations are low before the onset of obesity, and in the adult ob/ob mouse the prolactin response to stimulation with the dopamine receptor antagonist perphenazine is impaired. 4 Conversely, mice made obese by aurothioglucose injections or overfeeding show an exaggerated prolactin response to perphenazine, which returns to normal on weight reduction. ${ }^{6}$ Furthermore, the plasma concentration of growth hormone, which is reduced when these mice are obese, also becomes normal after weight loss. A direct extrapolation from rodent obesity to human obesity is not warranted. Nevertheless, the finding that in obese mice the patterns of prolactin and growthhormone responses depend on the type of obesity may be relevant to obesity in man.

We conclude from our findings that a disorder of hypothalamic function is present in massive obesity. The different patterns of prolactin response to insulin-induced hypoglycaemia suggest two types of human obesity. In type 1 (in which the subjects show no prolactin response to hypoglycaemia) the disorder of hypothalamic function may be due to a basic, possibly genetic abnormality. All of our 11 subjects in this group had been obese since early childhood. In type 2 (in which the subjects show a normal prolactin response to hypoglycaemia) the hypothalamic disorder is acquired and may be the result of chronic dietary excess; weight loss would be expected to result in complete normalisation of hypothalamic function. Seven of our nine subjects in this group had become obese either as teenagers or as adults.

The biochemical difference between these two types of obesity is clear: there is no overlap between the prolactin 
TABLE I-Clinical details and response to insulin tolerance test in obese subjects (classified according to prolactin response to hypoglycaemia) and controls

\begin{tabular}{|c|c|c|c|c|c|c|c|c|c|c|c|c|}
\hline \multirow[b]{2}{*}{$\begin{array}{l}\text { Case } \\
\text { No }\end{array}$} & \multirow[b]{2}{*}{$\underset{\text { (years) }}{\text { Age }}$} & \multirow[b]{2}{*}{$\begin{array}{l}\text { Age at } \\
\text { obesity }\end{array}$} & \multirow{2}{*}{$\begin{array}{l}\text { Weight (\% } \\
\text { of ideal } \\
\text { body } \\
\text { weight)* }\end{array}$} & \multirow[b]{2}{*}{$\begin{array}{l}\text { Family } \\
\text { history of } \\
\text { obesity }\end{array}$} & \multicolumn{2}{|c|}{$\begin{array}{l}\text { Blood glucose } \\
(\mathrm{mmol} / \mathrm{l})\end{array}$} & \multicolumn{2}{|c|}{ Prolactin } & \multicolumn{2}{|c|}{ Growth hormone } & \multicolumn{2}{|c|}{ Cortisol } \\
\hline & & & & & Fasting & $\underset{\text { during }}{\text { Minimum }}$ & $\underset{(\mathrm{mU} / \mathrm{l})}{\text { Basal }}$ & $\begin{array}{c}\text { Total } \\
\text { integrated } \\
\text { response }\end{array}$ & $\underset{(\mathrm{mU} / \mathrm{l})}{\text { Basal }}$ & $\underset{\substack{\text { Total } \\
\text { response }}}{\text { responsed }}$ & $\underset{(\mathrm{nmol} / \mathrm{l})}{\text { Basal }}$ & $\begin{array}{c}\text { Total } \\
\text { integrated } \\
\text { response }\end{array}$ \\
\hline $\begin{array}{c}1 \\
2 \\
3 \ddagger \\
4 \\
5 \\
6 \\
7 \\
8 \\
9 \\
10 \\
11\end{array}$ & $\begin{array}{l}34 \\
36 \\
44 \\
49 \\
27 \\
35 \\
32 \\
30 \\
27 \\
30 \\
27\end{array}$ & $\begin{array}{c}\text { Childhood } \\
\text { ", } \\
\text { ", } \\
\text { ", } \\
\text { ", } \\
\text { ", }\end{array}$ & $\begin{array}{l}200 \\
200 \\
220 \\
230 \\
280 \\
240 \\
200 \\
240 \\
220 \\
230 \\
240\end{array}$ & $\begin{array}{l}+ \\
++ \\
++ \\
+ \\
+ \\
+ \\
+ \\
+ \\
+ \\
+ \\
+\end{array}$ & $\begin{array}{l}5.0 \text { Non } \\
5 \cdot 0 \\
4 \cdot 2 \\
4.3 \\
3 \cdot 8 \\
3.8 \\
6 \cdot 4 \\
9 \cdot 8 \\
4 \cdot 3 \\
4 \cdot 7 \\
3 \cdot 7\end{array}$ & $\begin{array}{c}\text { responders } \\
1.5 \\
2.0 \\
1.4 \\
1.5 \\
1.0 \\
1.4 \\
1.5 \\
2.2 \\
0.7 \\
1.0 \\
1.5\end{array}$ & $\begin{array}{r}270 \\
230 \\
<60 \\
200 \\
1100 \\
270 \\
360 \\
220 \\
200 \\
140 \\
280\end{array}$ & $\begin{array}{r}-4 \\
-303 \\
0 \\
-105 \\
-100 \\
-49 \\
-148 \\
30 \\
-65 \\
-179 \\
22\end{array}$ & $\begin{array}{l}1 \cdot 0 \\
2 \cdot 2 \\
2 \cdot 1 \\
3 \cdot 2 \\
3 \cdot 6 \\
2 \cdot 2 \\
1 \cdot 3 \\
2 \cdot 4 \\
1 \cdot 5 \\
2 \cdot 7 \\
2 \cdot 3\end{array}$ & $\begin{array}{r}130 \\
427 \\
4694 \\
2391 \\
1664 \\
2464 \\
169 \\
1250 \\
3653 \\
744 \\
1324\end{array}$ & $\begin{array}{l}340 \\
580 \\
340 \\
430 \\
540 \\
590 \\
550 \\
400 \\
660 \\
530 \\
310\end{array}$ & $\begin{array}{r}+166 \\
-95 \\
+322 \\
+132 \\
+59 \\
-1 \\
-44 \\
-54 \\
+16 \\
+62 \\
0\end{array}$ \\
\hline Mean & $33 \cdot 7$ & & 227 & & $5 \cdot 2$ & 1.4 & 302 & -82 & $2 \cdot 2$ & 1719 & 479 & +51 \\
\hline $\begin{array}{l}12 \\
13 \\
14 \\
15 \\
16 \\
17 \\
18 \\
19 \\
20\end{array}$ & $\begin{array}{l}32 \\
46 \\
34 \\
34 \\
30 \\
38 \\
46 \\
20 \\
26\end{array}$ & $\begin{array}{l}\text { Childhood } \\
\text { Teenager } \\
\text { Adult } \\
\text { Teenager } \\
\text { „Childhood } \\
\text { Adult } \\
\text { Teenager }\end{array}$ & $\begin{array}{l}280 \\
200 \\
200 \\
260 \\
220 \\
200 \\
200 \\
200 \\
260\end{array}$ & $\begin{array}{l}+ \\
+ \\
+ \\
+ \\
+ \\
+ \\
+ \\
++\end{array}$ & $\begin{array}{ll} & R \\
5 \cdot 2 & R \\
4 \cdot 4 & \\
4 \cdot 8 & \\
4 \cdot 2 & \\
4 \cdot 2 & \\
5 \cdot 0 & \\
4 \cdot 9 & \\
4 \cdot 2 & \\
3 \cdot 5 & \end{array}$ & $\begin{array}{r}\text { sponders } \\
1.4 \\
1.0 \\
0.8 \\
1.3 \\
1.0 \\
1.0 \\
1.0 \\
1.0 \\
1.4\end{array}$ & $\begin{array}{l}<50 \\
140 \\
440 \\
300 \\
670 \\
300 \\
330 \\
500 \\
240\end{array}$ & $\begin{array}{r}+5300 \\
+398 \\
+1024 \\
+364 \\
+378 \\
+1812 \\
+1313 \\
+322 \\
+400\end{array}$ & $\begin{array}{l}2 \cdot 0 \\
3 \cdot 0 \\
2 \cdot 0 \\
2 \cdot 7 \\
2 \cdot 3 \\
2 \cdot 0 \\
2 \cdot 1 \\
2 \cdot 5 \\
2 \cdot 0\end{array}$ & $\begin{array}{r}2025 \\
2077 \\
3600 \\
227 \\
3668 \\
5410 \\
4694 \\
3852 \\
3965\end{array}$ & $\begin{array}{l}360 \\
350 \\
440 \\
410 \\
580 \\
540 \\
360 \\
610 \\
340\end{array}$ & $\begin{array}{r}+188 \\
+121 \\
+261 \\
+76 \\
+46 \\
+67 \\
+362 \\
-14 \\
+129\end{array}$ \\
\hline Mean & $34 \cdot 0$ & & 220 & & 4.5 & $1 \cdot 1$ & 330 & +1256 & $2 \cdot 3$ & 3279 & 443 & +137 \\
\hline $\begin{array}{l}21 \\
22 \\
23 \\
24 \\
25 \\
26\end{array}$ & $\begin{array}{l}28 \\
27 \\
24 \\
22 \\
18 \\
21\end{array}$ & & $\begin{array}{r}100 \\
95 \\
105 \\
100 \\
100 \\
100\end{array}$ & & & ontrols & $\begin{array}{l}200 \\
250 \\
250 \\
580 \\
190 \\
450\end{array}$ & $\begin{array}{r}+625 \\
+304 \\
+1368 \\
+970 \\
+478 \\
+1409\end{array}$ & $\begin{array}{l}4 \cdot 5 \\
3 \cdot 3 \\
2 \cdot 3 \\
0 \cdot 9 \\
5 \cdot 2 \\
3 \cdot 2\end{array}$ & $\begin{array}{r}12339 \\
5045 \\
3169 \\
669 \\
5912 \\
18377\end{array}$ & $\begin{array}{l}400 \\
400 \\
310 \\
230 \\
670 \\
220\end{array}$ & $\begin{array}{l}+136 \\
+154 \\
+155 \\
+341 \\
+14 \\
+862\end{array}$ \\
\hline Mean & $23 \cdot 3$ & & 100 & & & & 320 & +859 & $3 \cdot 2$ & 7585 & 370 & +277 \\
\hline
\end{tabular}

*Ideal body weight $=$ Midpoint of weight range for medium frame size, Metropolitan Life Insurance Co tables.

$\dagger=$ One parent obese. $++=$ Both parents obese. $-=$ No family history.

†Only male subject studied.

Conversion: SI to traditional units-Blood glucose: $1 \mathrm{mmol} / 1 \approx 18 \mathrm{mg} / 100 \mathrm{ml}$. Plasma cortisol: $1 \mathrm{nmol} / 1 \approx 0.036 \mu \mathrm{g} / 100 \mathrm{ml}$.

TABLE II-Significance of differences between groups ( $P$ values),* subjects being grouped according to prolactin response to hypoglycaemia

\begin{tabular}{llllccc}
\hline & & & Prolactin & $\begin{array}{c}\text { Growth } \\
\text { hormone }\end{array}$ & Cortisol \\
\hline Responders $v$ controls $\ldots$ & $\ldots$ & $\ldots$ & $\ldots$ & $>0.1$ & $>0.1$ & $>0.1$ \\
Non-responders $v$ controls & $\ldots$ & $\ldots$ & $\ldots$ & $<0.01$ & $<0.05$ & $<0.1$ \\
Non-responders $v$ responders &. & $\ldots$ & $\ldots$ & $<0.01$ & $<0.05$ & $<0.1$ \\
\hline
\end{tabular}

*Determined by Wilcoxon non-parametric test.

responses (table I). The difference in age of onset is less clearcut, however, since two patients apparently obese since early childhood had normal prolactin responses and it is uncertain whether their obesity may be considered to have a genetic basis.

We shall investigate the hypothesis that two types of human obesity exist in the same group of subjects after they have lost a substantial amount of weight.

We thank Professor J S Jenkius and Mr R Jackson for their help in measuring growth-hormone concentrations; the sister and nursing staff of ward 12, St James's Hospital, Balham; Mrs J Bateman, research dietitian; and Miss M Pattman for secretarial help. We are also grateful to the human reproduction unit of the World Health Organisation for its gifts of reagents used in the radioimmunoassay of prolactin and cortisol. PGK is supported by a research grant from the South-west Thames Regional Health Authority.

\section{References}

1 Kopelman PG, White N, Pilkington TRE, Jeffcoate SL. Impaired hypothalamic control of prolactin secretin in massive obesity. Lancet 1979; $1: 747-9$.

${ }^{2}$ Ball MF, El-Khodary AZ, Canary JJ. Growth hormone response in the thinned obese. 7 Clin Endocrinol Metab 1972;34:498-511.

3 Jung RT, Shetty PS, James WPT, Barrand MA, Callingham BA. Reduced thermogenesis in obesity. Nature 1979;279:322-3.

4 Larson BA, Sinha YN, Vanderlaan WP. Serum growth hormone and prolactin during and after the development of the obese-hyperglycemic syndrome in mice. Endocrinology 1976;98:139-45.

S Sinha YN, Salocks CB, Vanderlaan WP. Control of prolactin and growth hormone secretion in mice by obesity. Endocrinology, 1976;99:881-6.

(Accepted 9 October 1979)
ONE HUNDRED YEARS AGO A recent case, on which an inquest was held by Dr Hardwicke, shows clearly the necessity for the provision at all our police-stations of a system of ambulance conveyance to the nearest hospital, for persons found either sick, injured, or insensible. The poor fellow was a cabman, who had fallen backwards while lifting a heavy box on to his cab. He was conveyed by a policeman in his cab to the hospital, and on the way fell twice into the bottom of the cab; and on arrival, was found to be dead. Policeconstable $303 \mathrm{C}$ deposed that, whilst going along to the hospital in the $\mathrm{cab}$, the deceased coughed once or twice, and slipped down from the seat to the bottom of the cab, and he could not raise him without opening the door of the cab. In answer to questions as to why he did not procure a police-ambulance instead of letting a man in such a case lie in a heap at the bottom of a cab, he said they had not one at Marl- borough Street, and he did not know if there was one at Marylebone Lane, but there was one at the Vine Street Station. Mr E Fardon, resident medical officer of the hospital, said, on the deceased's arrival, he was dead. He had made a post mortem examination. There were no injuries to the back of the head, although the membranes of the brain were congested. The lungs were congested, and there was slight bronchitis, and there was disease of the mitral valves. The immediate cause of death was congestion of the brain, accelerated by the fall and the way in which deceased was brought to the hospital. The system of "help to the wounded" by our police needs reorganising; the practice of treating insensible people as "drunk and incapable," and of conveying men with fracture of the skull or in swooning from failure of the circulation, upright in a cab, is often little short of murderous. (British Medical fournal, 1880.) 